\title{
PHÂN TÍCH VÀ ĐÁNH GIÁ SỬ ẢNH HƯởNG CỦA NHIỂT ĐỘ VÀ HIỆN TƯợNG PHỦ BÓNG ĐẾN HIỆU QUẢ PHÁT ĐIỆN CỦA TẨM QUANG ĐIỆN
}

\author{
BẠCH THANH QUÝ
}

\author{
Khoa Công Nghệ Điện, Trường Đại học Công nghiệp Thành phố Hồ Chí Minh \\ bachthanhquy@iuh.edu.vn
}

\begin{abstract}
Tóm tắt. Trong xu hướng tìm kiếm nguồn năng lượng mới để thay thế cho nguồn năng lượng truyền thống, năng lượng mặt trời được đánh giá có nhiều tiềm năng và ưu điểm để khai thác và phát triển tại nước ta hiện nay. Nhằm góp phần hiểu rõ hơn tính chất của nguồn năng lượng này, bài viết trình bày các đặc tính cơ bản của một hệ thống quang năng, đồng thời chú trọng đến phân tích và đánh giá hai yếu tố chính tác động đến hiệu quả phát điện của một hệ thống solar đó là nhiệt độ và hiện tượng phủ bóng. Thông qua kết quả phân tích, làm cơ sở kỹ thuật cho các đơn vị thực hiện thi công, lắp đặt, vận hành, và bảo trì hệ thống quang năng đảm bảo ngoài việc hệ thống hoạt động còn phải tối ưu công suất phát của hệ thống.
\end{abstract}

Từ khóa. Năng lượng tái tạo, năng lượng mặt trời, pin mặt trời, hệ thống quang năng.

\section{ANALYZING AND EVALUATING THE AFFECTIVE OF TEMPERATURE AND SHADING TO THE EFFICIENCY OF A SOLAR POWER GENERATION.}

\begin{abstract}
On the trend of seeking new energy soures in order to replace traditional energy, solar energy is considered to have high potential and advantages to be exploited and developed in our country. In this paper, first, basic characteristics of a photovoltaic system are presented. The affects of temperature and shadow to the efficiency of a solar power generation are analyzed and evaluated in the second part of the paper. This results are then used as technical recommendation/materials for workers in order to install, operate and maintain solar systems such that the output energy generation is optimized.
\end{abstract}

Keywords. Renewable energy, solar energy, solar cell, photovoltaic system.

\section{1 ĐẠT VẤN ĐỀ}

Tăng cường khai thác nguồn năng lượng sạch để thay thế các nguồn năng lượng hoá thạch truyền thống đang là xu hướng phát triển hiện nay. Các nguồn năng lượng có tính bền vững, và ít gây ô nhiễm được xem xét tại nước ta đó là: Các hồ thuỷ điện nhỏ, phong năng, quang năng và năng lượng sinh khối. Theo [1], chi phí sản xuất năng lượng tái tạo trong 5 năm gần đây đã giảm đáng kể, có thể thu hút được các nhà đầu tư tham gia vào phát triển nguồn năng lượng tái tạo.

Đầu tiên, với các hồ thuỷ điện nhỏ được đánh giá là có giá thành đổi điện thấp nhất, khả năng sản xuất ổn định và kết nối lưới tốt, tuy nhiên tại nước ta hiện nay nguồn tài nguyên năng lượng này đã được khai thác hết tiềm năng đang có.

Tiếp theo là tài nguyên năng lượng gió, Việt Nam có vị trí địa lý thuận lợi, có đường bờ biển dài, nguồn năng lượng gió được đánh giá khá tốt (năng lượng gió khai thác trên $6 \mathrm{~m} / \mathrm{s}$ ), có một vài nhà máy điện gió đã được triển khai và nối lưới, tuy nhiên việc đổi điện của nguồn năng lượng này vẫn còn nhiều hạn chế trong quá trình khai thác và vận hành hệ thống phát điện gió như: Ổn định tần số, công suất phát, tính ổn định khi hệ thống nối lưới, và giá thành biến đổi điện cao ...., nên việc khai thác và phát triển nguồn năng lượng này vẫn còn nhiều hạn chế cần khắc phục.

Kế đển là nguồn phát điện từ sinh khối, về cơ bản, nước ta được đánh giá là có thế mạnh về khai thác nông nghiệp, nên nguồn nguyên liệu sinh khối có trữ lượng lớn, có tiềm năng trong việc chuyển đổi năng lượng sinh khối sang điện năng, tuy nhiên công nghệ phát điện sinh khối vẫn còn rất nhiều vấn đề phát sinh trong việc xử lý sinh khối, xử lý môi trường và giá thành đổi điện vẫn còn rất cao, nên nguồn tài nguyên này chưa mang lại hiệu quả khai thác. 
Về năng lượng quang năng, Việt Nam được đánh giá là một trong những nước có trữ lượng năng lượng mặt trời lớn. Theo kết quả đánh giá sơ bộ của Chương trình Trợ giúp Năng lượng MOIT/GIZ năm 2016 [2], [3], tiềm năng năng lượng mặt trời của Việt Nam khoảng $130 \mathrm{GW}$, là một trữ lượng vô cùng lớn cần được khai thác và phát triển để đáp ứng tốt nguồn cung năng lượng cho công nghiệp và dân sinh, giảm bớt áp lực phụ thuộc lên nguồn năng lượng hoá thạch, công nghệ khai thác và chuyển đổi quang năng trong những năm gần đây liên tục được cải tiến đã làm giảm khá sâu giá thành biến đổi điện năng, do đó, nguồn năng lượng này được xem là nguồn năng lượng có khả năng khai thác và phát triển nhẩt hiện nay.

Gần đây, với sự khuyến khích của chính phủ bằng các văn bản quy phạm pháp luật cho phép khai thác và kinh doanh năng lượng mặt trời hoà lưới, hàng loạt dự án về năng lượng mặt trời được cấp phép triển khai. Song song với các dự án năng lượng mặt trời lớn, thì một phần không thể không nhắc đến đó là năng lượng mặt trời trên mái nhà. Việc lắp đặt các tấm quang điện trên mái nhà phát ra công suất điện cho phụ tải chính ngôi nhà đó, ngoài ra còn có thể hoà vào lưới trong những thời điểm có nắng nhưng không sử dụng điện.

Tuy nhiên, việc lắp đặt các tấm quang điện lên mái nhà vì chạy theo cạnh tranh giá thành lắp đặt và thi công nên thường được lắp trực tiếp lên mái nhà mà không thi công khung giá đỡ riêng cho hệ thống năng lượng, dẫn đến có sự tích nhiệt cao phía bên dưới tấm quang điện, nhiệt độ này tác động xấu đến hệ thống phát điện và về lâu dài không tốt cho cả hệ thống, làm giảm tuổi thọ của hệ năng lượng mặt trời hay giảm công suất phát của hệ thống mặt trời. Ngoài ra vì tiết kiệm không gian, các hệ thống năng lượng mặt trời thường không khảo sát các hiện tượng phủ bóng lên một phần tấm quang điện, yếu tố này cũng ảnh hưởng không nhỏ đến đặc tính phát điện của hệ thống. Trong bài viết này, tác giả đi phân tích hai yếu tố có ảnh hưởng lớn đến tính chất phát điện của hệ thống năng lượng mặt trời đó là nhiệt độ và sự phủ bóng lên các tấm quang điện. Kết quả phân tích cho thấy cần phải có biện pháp giảm sự tích nhiệt làm việc của tấm quang điện và thực hiện các biện pháp bảo trì, bảo dưỡng các tấm quang điện sao cho giảm nhỏ nhất hệ sự phủ bóng lên bề mặt làm việc của các tấm quang điện.

\section{MÔ HİNH HOÁ VÀ CÁC ĐặC TÍNH CỦA TẾ BÀO QUANG ĐIỆN.}

Cấu tạo của một tế bào quang điện gồm hai lớp bán dẫn n-p; khi ánh sáng mang các hạt năng lượng photon chiếu vào tế bào quang điện làm giải phóng các electron tự do trong hợp chất bán dẫn, tạo nên các hạt hạt mang điện tích âm và các lỗ trống mang điện tích dương, các điện tích âm và điện tích dương tập trung về hai phía của hai lớp bán dẫn n-p tạo ra sự phân cực trong tế bào quang điện. Chính sự phân cực này tạo nên điện thế tại hai bề mặt lớp $n-p$. Nối hai điện cực này với một điện trở bên ngoài sẽ tạo nên dòng điện, gọi là dòng phân cực $\mathrm{I}_{\mathrm{ph}}$, như hình 1 .

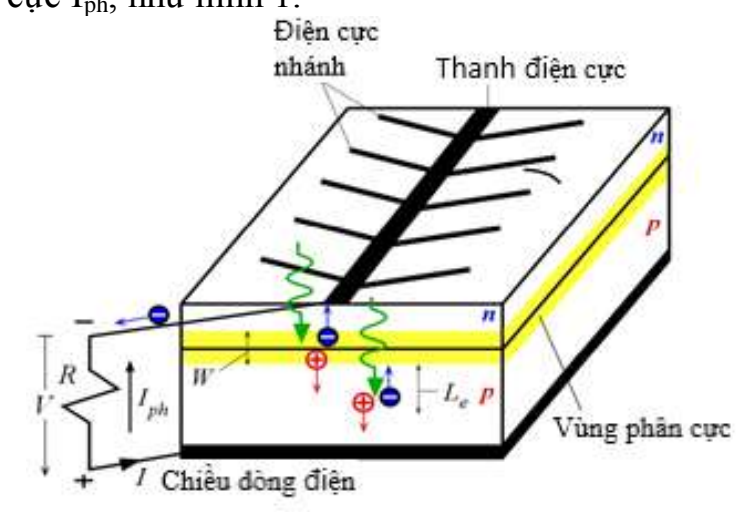

Hình 1: Cấu tạo và nguyên lý của tế bào quang điện

Như vậy với một tế bào quang điện được xem tương đương với một diode quang bán dẫn. Tiến hành nối tắt hai điện cực của tế bào quang điện, ta có mô hình nguyên lý như hình 2 . 


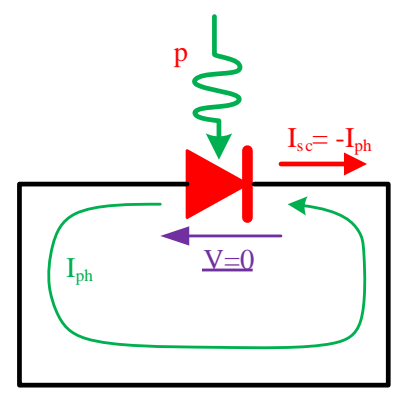

Hình 2: Sơ đồ nối ngắn mạch tế bào quang điện

Theo hình 2 , khi ngắn mạch, điện thế ngược trên hai đầu diode bằng 0 , dưới tác động phân cực của các photon, sinh ra một dòng điện chạy trong mạch, gọi là dòng nguồn $\mathrm{I}_{\mathrm{ph}}$ (Photocurrent source). Dòng điện nguồn ngắn mạch được xác định:

$$
\mathrm{I}_{\mathrm{sc}}=-\mathrm{I}_{\mathrm{ph}}
$$

Dòng $\mathrm{I}_{\mathrm{ph}}$ là một hàm số phụ thuộc các yếu tố như vật liệu chế tạo, nhiệt độ làm việc, và cường độ ánh sáng chiếu lên các tế bào quang điện, theo [4], $\mathrm{I}_{\mathrm{ph}}$ được xác định:

$$
\mathrm{I}_{\mathrm{ph}}=\mathrm{K} . \mathrm{I}
$$

Trong đó: $\mathrm{K}$ là hằng số phụ thuộc thiết bị, bao gồm: Công nghệ chế tạo, vật liệu chế tạo và nhiệt độ môi trường làm việc, và $I$ là cường độ bức xạ ánh sáng.

Tiến hành nối hai điện cực của tế bào quang điện với một tải trở $R$, ta có mô hình nguyên lý như hình 3.

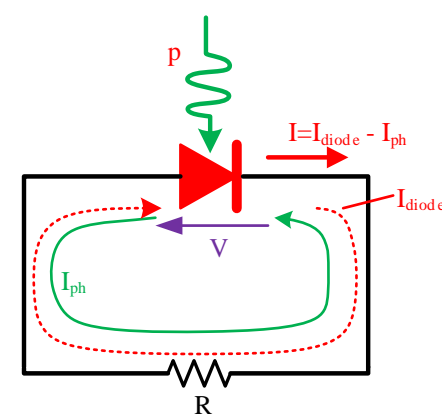

Hình 3: So đồ nối tế bào quang điện với tải $R$

Theo hình 3 , khi nối hai đầu điện cực của tế bào quang điện với điện trở thì điện áp đặt lên hai đầu điện trở cũng chính là điện áp đặt thuận lên diode, do đó xuất hiện một dòng điện qua diode, ngược chiều hoàn toàn với dòng $\mathrm{I}_{\mathrm{ph}}$. Dòng điện lấy ra của tế bào quang điện lúc này là $\mathrm{I}$, và $\mathrm{I}$ được xác định theo công thức (3).

$$
\mathrm{I}=\mathrm{I}_{\text {diode }}-\mathrm{I}_{\mathrm{ph}}
$$

Để thuận tiện trong việc phân tích và tính toán cũng như mô phỏng, một tế bào quang điện được xem như một nguồn dòng lý tưởng nối song song với một diode như sơ đồ hình 4.

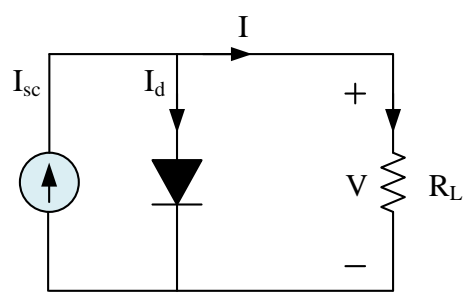

Hình 4: So đồ mạch điện tương đương lý tương. 
Hình 4 là mô hình với một diode lý tưởng, khi đó nội trở nối tiếp $\mathrm{R}_{\mathrm{s}}=0$, và nội trở song song $\mathrm{R}_{\mathrm{sh}}=$ $\infty$. Tuy nhiên, với một diode thực tế, hai giá trị nội trở $\mathrm{R}_{\mathrm{s}}$ và $\mathrm{R}_{\mathrm{sh}}$ luôn luôn tồn tại, do đó sơ đồ mạch điện tương đương của một tế bào quang điện được trình bày như trong hình 5 .

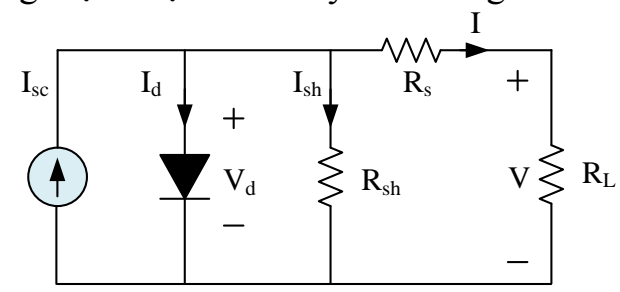

Hình 5: So đồ mạch điện tưong đương thực tế của solar cell

Áp dụng định luật Kirchoff 1, để phân tích mạch tương đương trong hình 5, ta có:

$$
\mathrm{I}=\mathrm{I}_{\mathrm{sc}}-\mathrm{I}_{\mathrm{d}}-\mathrm{I}_{\mathrm{sh}}
$$

Trong công thức (4), $\mathrm{I}_{\mathrm{sc}}$ là cường độ dòng điện ngắn mạch phát ra từ các tế bào quang điện dưới tác động của cường độ bức xạ ánh sáng, $\mathrm{I}_{\mathrm{d}}$ cường độ dòng điện qua diode ngược, và $\mathrm{I}_{\mathrm{sh}}$ là cường độ dòng điện qua nội trở song song của tế bào quang điện. Xem xét dòng điện qua diode, tính dòng điện qua nội trở shunt của diode, thay thế vào công thức (4) ta có:

$$
I=I_{s c}-I_{0}\left(e^{\frac{q\left(V+I R_{S}\right)}{n k T}}-1\right)-\frac{V+I R_{S}}{R_{s h}}
$$

Trong (5), $\mathrm{n}$ là hệ số đặc tính của diode, $\mathrm{k}$ là hằng số Boltzmann, $\mathrm{T}$ là nhiệt độ ( $\left.{ }^{0} \mathrm{~K}\right)$, và $\mathrm{q}$ là điện tích. Theo [5], $\mathrm{I}_{0}$ được gọi là dòng điện bảo hoà ngược qua diode $\mathrm{I}_{\text {sat }}$ (Reverse saturation current), hay còn gọi là dòng điện tối. Dòng điện tối được xác định bằng công thức (6).

$$
I_{0}=I_{r r}\left[\frac{T}{T_{r}}\right]^{3} \exp \left[\frac{q E_{g a p}}{n k}\left(\frac{1}{T_{r}}-\frac{1}{T}\right)\right]
$$

Trong (6), $\mathrm{T}_{\mathrm{r}}$ là nhiệt độ tham chiếu của tế bào quang điện $\left({ }^{0} \mathrm{~K}\right), \mathrm{I}_{\mathrm{rr}}$ là dòng điện tối tương ứng với nhiệt độ tham chiếu, và $\mathrm{E}_{\text {gap }}$ là năng lượng tối thiểu cần thiết của vật liệu bán dẫn tạo ra. Đặc tính dòng điện tối qua diode được trình bày như hình 6.

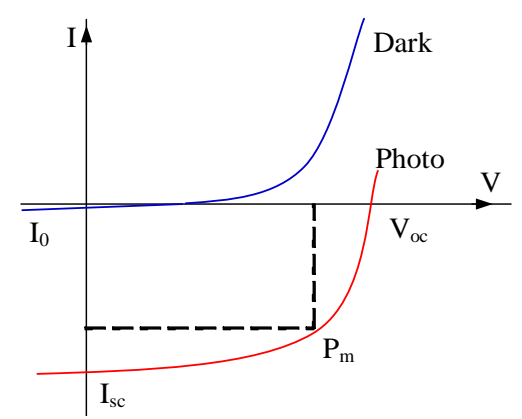

Hình 6: Đặc tính I-V của Iph và IO.

Cũng theo [5], cường độ dòng ngắn mạch của tế bào quang điện $\left(\mathrm{I}_{\mathrm{sc}}\right)$ được xác định là một hàm của bức xạ mặt trời trên bề mặt tấm pin $\mathrm{S}_{\mathrm{i}}$, và nhiệt độ tấm pin $\mathrm{T}$, được xác định theo công thức (7).

$$
\mathrm{I}_{\mathrm{sc}}=\mathrm{I}_{\mathrm{scr}}+\frac{\mathrm{K}_{\mathrm{i}}}{1000}\left(\mathrm{~T}-\mathrm{T}_{\mathrm{r}}\right) \mathrm{xS}_{\mathrm{i}}
$$

Trong (7), $\mathrm{I}_{\mathrm{scr}}$ là cường độ dòng điện ngắn mạch của các tế bào quang điện phát ra ở nhiệt độ tham chiếu $\mathrm{T}_{\mathrm{r}}$ và cường độ bức xạ tiêu chuẩn $1 \mathrm{kWp} / \mathrm{m}^{2}, \mathrm{~K}_{\mathrm{i}}(\mathrm{mA} / 0 \mathrm{C})$ hệ số ảnh hưởng nhiệt của tế bào quang điện.

\section{3 ẢNH HƯỞNG CỦA NHIẸT ĐỘ ĐẾN CÔNG SUÂTT PHÁT}

Từ sơ đồ mạch tương hình 5 , công suất điện phát ra tải của tế bào quang điện được xác định theo công thức (8).

$$
P=I V=I_{s c} \mathrm{~V}-I_{0} V\left(e^{\frac{q \mathrm{~V}}{n k T}}-1\right)
$$


Trong công thức (8), vì thành phần $\mathrm{R}_{\mathrm{s}} \leq \mathrm{R}_{\mathrm{sh}}$ không gây ảnh hưởng nhiều đến kết quả tính toán nên đã được lượt bỏ. Tiến hành phân tích trên cùng một loại tế bào quang điện tiêu chuẩn, với cường độ bức xạ tiêu chuẩn $\mathrm{S}=1000 \mathrm{~W} / \mathrm{m} 2$, tương ứng thành phần nhiệt độ thay đổi theo 4 mức $60^{\circ} \mathrm{C}, 25^{\circ} \mathrm{C}, 0^{\circ} \mathrm{C}$, và $-10^{\circ} \mathrm{C}$, ta có đặc tính $\mathrm{I}-\mathrm{V}$, và đặc tính $\mathrm{P}-\mathrm{V}$ như hình 7 và hình 8 .

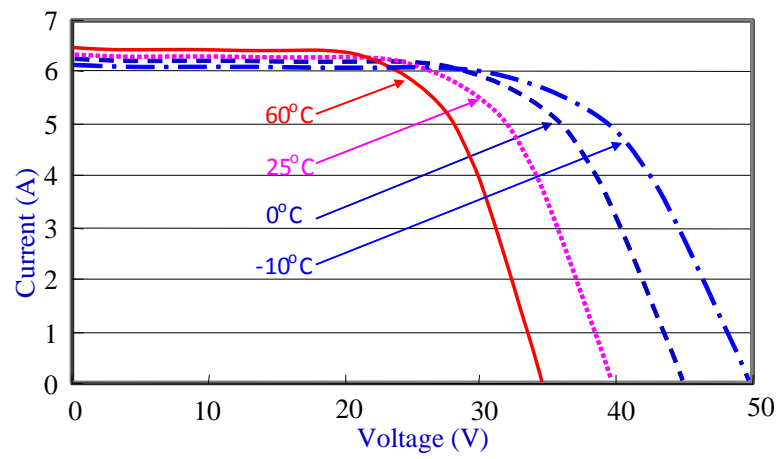

Hình 7: Đặc tính I-V theo nhiệt độ.

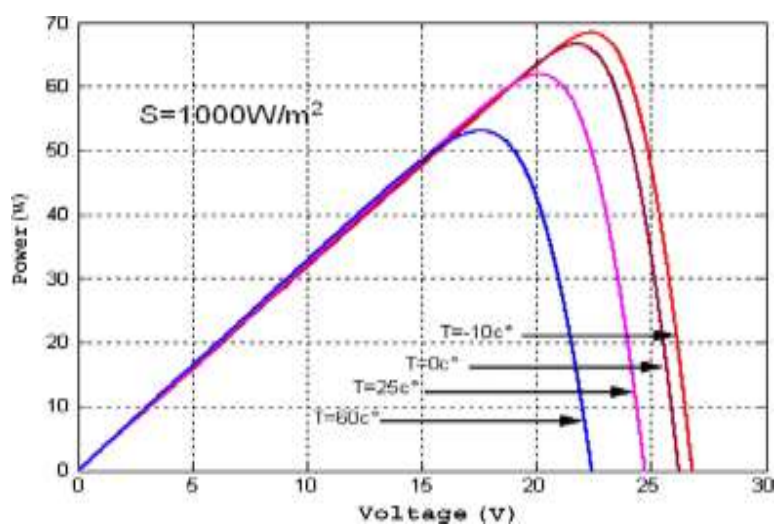

Hình 8: Đặc tính P-V theo nhiệt độ.

Từ kết quả mô phỏng hình 7 và hình 8 , nhận thấy rằng khi nhiệt độ thay đổi, công suất phát của pin mặt trời cũng thay đổi rất lớn, điện áp và dòng điện cũng thay đổi theo hướng nhiệt độ càng giảm thì đặc tuyến $\mathrm{I}-\mathrm{V}$ càng mở rộng, điểm làm việc có công suất cực đại của tấm pin càng lớn. Tính chất này cần đặc biệt chú ý khi tiến hành thiết kế, thi cồng và lắp đặt các tấm quang điện, việc thông gió giải nhiệt để giảm nhiệt độ làm việc của các tấm quang điện cho phép ta thu được công suất điện cao hơn.

\section{HIỆN TƯợNG PHỦ BÓNG BỀ MặT Hệ THỐNG QUANG NĂNG}

Một hệ thống năng lượng bao gồm các mạch nối tiếp và song song của nhiều tế bào quang điện để tạo nên một hệ thống phát điện quang năng có dòng điện và điện áp cần thiết, được gọi là hệ thống quang năng. Khi gắn nối tiếp sẽ làm tăng điện áp tổng trong mạch, khi gắn song song sẽ làm tăng cường độ dòng điện tổng trong mạch. Vấn đề phủ bóng lên một phần hoặc toàn bộ các phần tử trong mạch nối tiếp và song song của các tấm quang điện, làm ảnh hưởng đến công suất phát của tấm quang năng.

Hiện tượng phủ bóng lên hệ thống năng lượng mặt trời đang vận hành là thường xuyên xãy ra, nguyên nhân thường là sự che khuất của nhành cây, toà nhà, đám mây, lá cây, bóng chim, bụi bẩn hay các vật thể lạ khác $[6,7,8], \ldots$. Sự che khuất này chỉ làm cho một hoặc vài tấm pin trong hệ thống năng lượng trở nên xấu đi, không phát được công suất, ảnh hưởng đến công suất của toàn hệ thống. Sự xấu đi của các phần tử trong hệ thống cũng có thể đến từ sự xuống cấp của sản phẩm, hoặc sản phẩm lỗi từ nhà sản xuất nhưng vẫn được lắp đặt,..., các phần tử lổi này có thể nối tiếp hoặc song song trong hệ thống, do đó cần tiến hành phân tích hai trường hợp: Hai phần tử song song và hai phần tử nối tiếp. 
Trường họ̣p 01: Hai phần tử quang điện được ghép song song như hình 9.

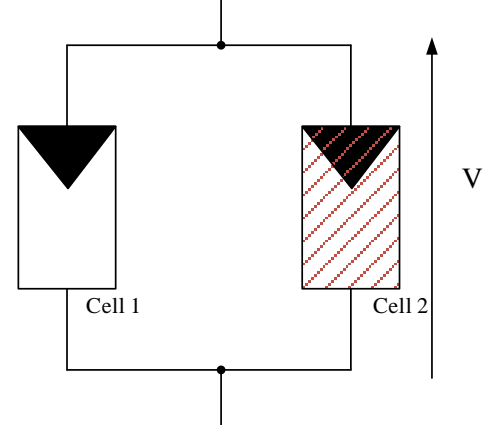

Hình 9: Hai phần tử quang điện nối song song.

Trong hình 9 , phần tử cell 1 và cell 2 bình thường hoạt động tốt, sẽ phát ra dòng điện $I_{1}$ và $I_{2}$ cùng cấp điện áp $\mathrm{V}$, dòng điện tổng trong mạch sẽ là $\mathrm{I}=\mathrm{I}_{1}+\mathrm{I}_{2}$. Vì lý do phủ bóng, giả sử cell 2 trở nên xấu đi, đặc tính $\mathrm{I}-\mathrm{V}$ của hai phẩn tử quang điện được trình bày như hình 10 .

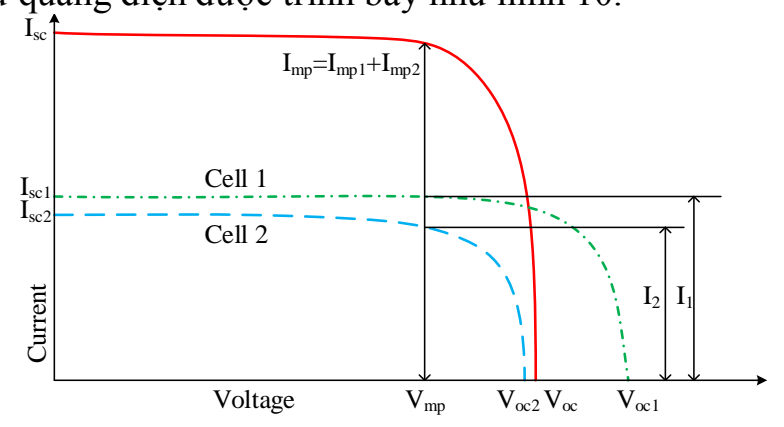

Hình 10: Đặc tuyến I-V của hai phần tư quang điện không đồng nhất nối song song.

Dòng điện phát ra của phần tử cell 2 nhỏ hơn so với bình thường, ảnh hưởng đến dòng điện tổng trong mạch. Điện áp phát ra của phần tử cell 2 cũng nhỏ hơn bình thường so với phần tử cell 1 , do hai cell được nối song song, do đó tổng điện áp trên hai cell phải bằng không (Định luật Kirchoff 2). Bằng phương pháp đảo đồ thị đặc tính $\mathrm{I}-\mathrm{V}$ trên trục điện áp của một cell bất kỳ ta xác định được giao điểm hai đặc tính, giao điểm là điện áp của hai cell song song, như hình 11.

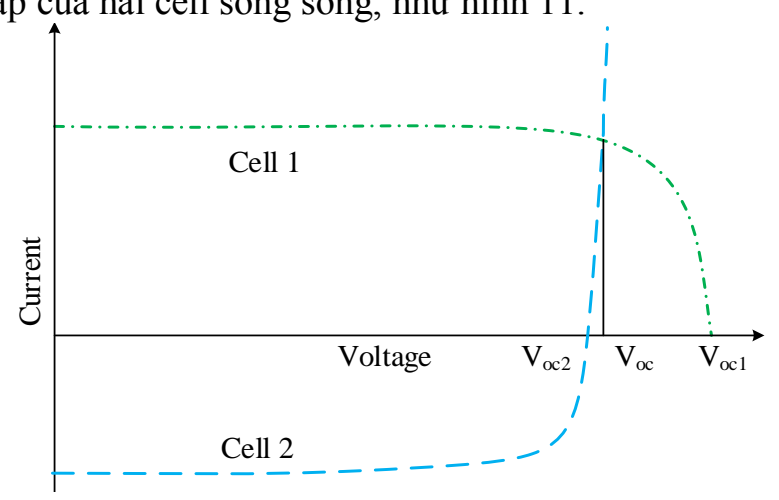

Hình 11: Xác định giao điểm điện áp hai cell không đồng nhất ghép song song.

Từ hình 11, nhận thấy khi hai phần tử quang điện ghép song song, điện áp xác lập của mạch sẽ giảm đi theo điện áp của phần tử lỗi, việc này ảnh hưởng không nhỏ đến tính năng phát điện của hệ thống quang năng, yếu tố sụt áp gây ảnh hưởng rất lớn đến các thiết bị tải cũng như đối với các hệ thống điện mặt trời hoà lưới. 
Trường hợp 02: Hai phần tử quang điện được ghép nối tiếp như hình 12.

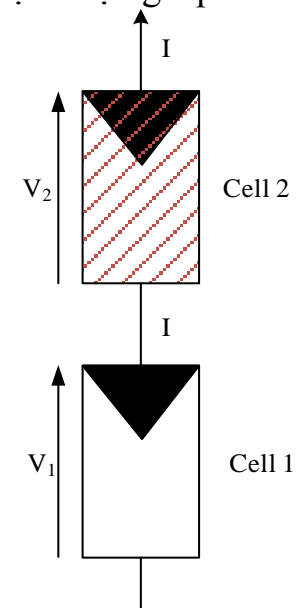

Hình 12: Hai phần tử quang điện nối nối tiếp.

Tương tự như trường hợp 1 , ghép nối tiếp hai phần tử quang điện với mục đích tăng điện áp trong mạch $\mathrm{V}=\mathrm{V}_{1}+\mathrm{V}_{2}$, với cùng một dòng điện $\mathrm{I}$. Giả sử, phần tử quang điện cell 2 trong mạch trở thành phần tử lỗi, đặc tuyến $\mathrm{I}-\mathrm{V}$ của hai phần tử quang điện được trình bày như hình 13.

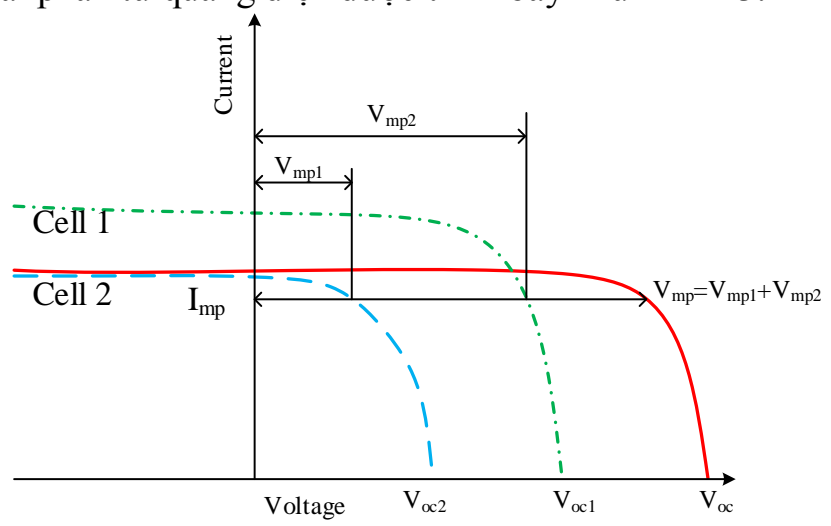

Hình 13: Đặc tính I-V của hai phần tử quang điện không đồng nhất ghép nối tiếp.

Nhận thấy điện áp trên phần tử lỗi cell 2 hoàn toàn giảm so với bình thường, do đó điện áp điểm làm việc của mạch $\mathrm{V}_{\mathrm{mp}}$ sẽ bị tác động giảm. Dòng điện ngắn mạch của hai cell lúc này cũng bị ảnh hưởng, dòng điện chạy trong mạch lúc này chính là dòng $\mathrm{I}_{\mathrm{sc} 2}$, do vậy tổng công suất phát ra của mạch bị ảnh hưởng rất nhiều.

\section{KIỂM NGHIỆM HIỆN TỰ̛̣G PHỦ BÓNG BÀNG BỘ KIT THÍ NGHIỆM QUANG NĂNG}

Kiểm chứng thực nghiệm, tiến hành xây dựng bộ Kit thí nghiệm năng lượng mặt trời, mô phỏng gần giống thực tế để tiến hành kiểm nghiệm và đánh giá các tính chất cơ bản của một hệ thống quang năng. Các thành phần của bộ Kit được trình bày như hình 14 . 


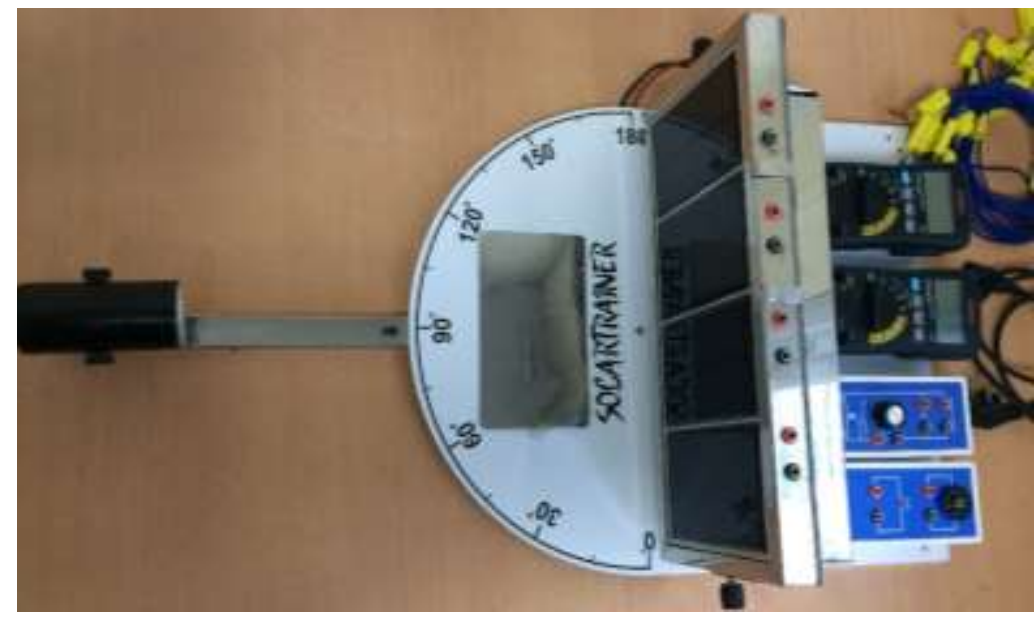

Hình 14: Mô hình bộ Kit thí nghiệm năng lượng mặt trời.

Các khối thiết bị trong mô hình có thể tháo rời, nguồn bức xạ nhân tạo được sử dụng là một bóng đèn halogen sợi đốt, phát ra ánh sáng và nhiệt độ màu gần với nguồn sáng mặt trời nhất, có thể điều chỉnh độ sáng bằng dimmer để thay công suất chiếu sáng. Nguồn sáng có thể xoay quanh hệ thống năng lượng $180^{\circ}$ cho mục đích chuyển động mô phỏng từ đông sang tây của mặt trời. Hệ thống quang năng được chế tạo thành 4 tấm riêng biệt để có thể tiến hành ghép nối tiếp hoặc song song khi cần, bảng chứa các tấm quang điện có thể nghiêng từ 0 đến $90^{\circ}$ dùng mô phỏng độ nghiêng của hệ thống thực, mỗi tấm quang điện được lựa chọn kích thước $86 \times 150 \mathrm{~mm}$, có thể phát ra công suất tối đa $1.8 \mathrm{~W}$ (ở bức xạ tiêu chuẩn), điện áp hở mạch $6 \mathrm{~V}$, dòng ngắn mạch $350 \mathrm{~mA}$.

Ngoài hai thành phần chính nêu trên, còn có các thiết bị khác như thiết bị đo, các loại tải, bộ lưu điện, bộ đổi điện $\mathrm{DC}-\mathrm{AC}$, các loại lá chắn ánh sáng dùng cho mô phỏng hiện tượng phủ bóng (gồn $1 / 4$ tấm, $1 / 2$ tấm và phủ toàn bộ), dây nối ..... Trong quá trình thực nghiệm thiết bị đo được chọn là đồng hồ số CD771 hiệu sanwa, có thể đo dòng tầm $\mu \mathrm{A}$ đến $10 \mathrm{~A}$ xoay chiều lẫn một chiều.

Lựa chọn các trường hợp thực nghiệm phù hợp như sau:

Trường hợp 1: Điện áp hở mạch $\mathrm{V}_{\mathrm{oc}}[\mathrm{mV}]$ và dòng ngắn mạch $\mathrm{I}_{\mathrm{sc}}[\mathrm{mA}]$ của một tấm quang điện khi có mức độ phủ bóng khác nhau.

Mô hình có 4 tấm quang điện, theo thứ tự gọi là cell $1,2,3$ và 4 , trong đó cell 1 và 4 ở vị trí ngoài cùng nên chịu mức độ chiếu sáng yếu hơn hai cell 2 , và 3 khi nguồn sáng được đặt tại vuông góc bề mặt các tấm quang điện. Lựa chọn cell 2 tiến hành thực nghiệm với mức độ phủ bóng khác nhau, nguồn bức xạ được điều chỉnh ở mức chiếu sáng tối đa, nguồn sáng vuông góc với bề mặt của các tấm quang điện. Sử dụng đồng hồ đo dòng điện và điện áp đo giá trị điện áp hở mạch $\mathrm{V}_{\mathrm{oc}}$ và dòng ngắn mạch $\mathrm{I}_{\mathrm{sc}}$ như hình 15 và kết quả được trình bày trong bảng 1 .

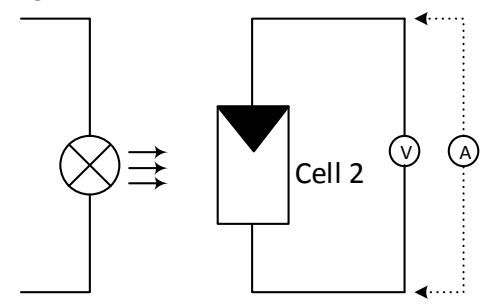

Hình 15: Sơ đồ thí nghiệm đo Voc và Isc với cell 2.

Bảng 1: Bảng ghi giá trị Voc và Isc cho cell 2 theo mức độ che phủ

\begin{tabular}{|c|c|c|c|c|}
\hline $\begin{array}{c}\text { Bể mặt tấm quang } \\
\text { năng }\end{array}$ & $\begin{array}{c}\text { Phủ hoàn } \\
\text { toàn }\end{array}$ & Phủ $1 / 2$ & Phủ $1 / 4$ & Không phủ \\
\hline $\mathrm{U}_{\mathrm{oc}}[\mathrm{V}]$ & 0,05 & 3,315 & 4,87 & 5,78 \\
\hline $\mathrm{I}_{\mathrm{sc}}[\mathrm{mA}]$ & 0 & 40 & 178 & 215 \\
\hline
\end{tabular}


Theo bảng 1 , khi tiết diện bề mặt tấm quang điện bị phủ bóng càng tăng lên thì khả năng phát điện của tấm quang điện càng giảm xuống, thậm chí hoàn toàn không phát (Trường hợp bị phủ bóng hoàn toàn).

Trường hợp 2: Sử dụng các tấm quang điện ghép nối tiếp, thực nghiệm các trường hợp có và không có phủ bóng.

Ghép nối tiếp các tấm quang điện lại với nhau, nguồn bức xạ sử dụng mức chiếu sáng tối đa, sơ đồ thực nghiệm như hình 16.

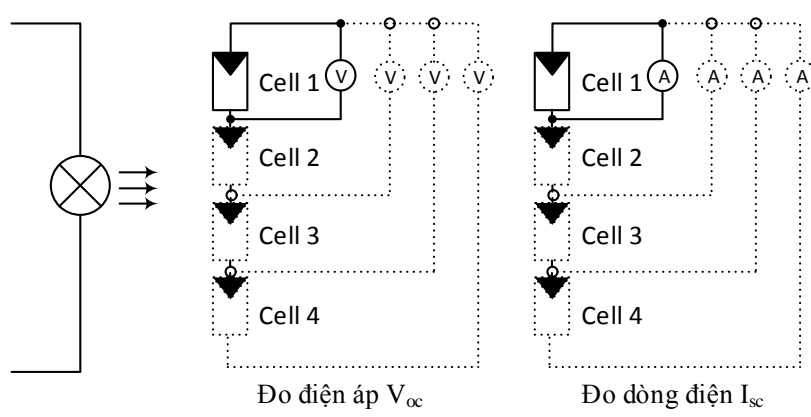

Hìn 16: So đồ ghép nối tiếp các tấm quang điện.

Đầu tiên, tiến hành đo $\mathrm{V}_{\mathrm{oc}}$ và $\mathrm{I}_{\mathrm{sc}}$ của từng tấm quang điện riêng biệt, kết quả được trình bày trong bảng 2 .

Bảng 2: Bảng ghi giá trị Voc và Isc của tùng cell riêng lẻ.

\begin{tabular}{|c|c|c|c|c|}
\hline & Cell 1 & Cell 2 & Cell 3 & Cell 4 \\
\hline $\mathrm{U}_{\mathrm{oc}}[\mathrm{V}]$ & 5,13 & 5,78 & 5,65 & 5,10 \\
\hline $\mathrm{I}_{\mathrm{sc}}[\mathrm{mA}]$ & 125 & 235 & 220 & 110 \\
\hline
\end{tabular}

Tiếp theo, tiến hành đo $\mathrm{V}_{\mathrm{oc}}$ và $\mathrm{I}_{\mathrm{sc}}$ các tấm quang điện gắn nối tiếp nhau, kết quả đo được như trong bảng 3.

Bảng 3: Bảng ghi giá trị Voc và Isc khi các cell lần lượt gắn nối tiếp.

\begin{tabular}{|c|c|c|c|c|}
\hline & Cell 1 & $\begin{array}{c}\text { Nối tiếp cell 1, } \\
2\end{array}$ & $\begin{array}{c}\text { Nối tiếp cell 1, 2, } \\
3\end{array}$ & $\begin{array}{c}\text { Nối tiếp cell 1, 2, 3, } \\
4\end{array}$ \\
\hline $\mathrm{U}_{\mathrm{oc}}[\mathrm{V}]$ & 5,2 & 11,25 & 16,69 & 21,82 \\
\hline $\mathrm{I}_{\mathrm{sc}}[\mathrm{mA}]$ & 126 & 130 & 172 & 160 \\
\hline
\end{tabular}

Để kết thúc thực nghiệm trong trường hợp 2 này, tiến hành sử dụng các tấm phủ bóng, lần lược tiến hành 4 trường hợp đo: cả 4 cell không phủ; cell 2 phủ $1 / 4$; cell 2 phủ $1 / 4$ và cell 3 phủ $1 / 2 ;$ cell 2 phủ $1 / 4$, cell 3 phủ $1 / 2$ và cell 4 phủ hoàn toàn. Kết quả đo $V_{\mathrm{oc}}$ và $\mathrm{I}_{\mathrm{sc}}$ được ghi trong bảng 4 .

Bảng 4. Bảng ghi giá trị Voc và Isc cho 4 trường hợp phủ bóng trong mạch nối tiếp

\begin{tabular}{|c|c|c|c|c|}
\hline & $\begin{array}{c}\text { Tất cả không } \\
\text { phủ }\end{array}$ & $1 / 4($ cell 2) & $\begin{array}{c}1 / 4(\text { cell 2)+ } 1 / 2(\text { cell } \\
3)\end{array}$ & $\begin{array}{c}1 / 4(\text { cell 2)+ } 1 / 2 \\
\text { (cell 3)+phủ cell } \\
4\end{array}$ \\
\hline $\mathrm{U}_{\mathrm{oc}}[\mathrm{mV}]$ & 21,65 & 19,8 & 16,22 & 9,82 \\
\hline $\mathrm{I}_{\mathrm{sc}}[\mathrm{mA}]$ & 145 & 120 & 60 & 0 \\
\hline
\end{tabular}

Kết quả có được từ bảng 2, nhận thấy các tấm quang điện có cùng thông số kích thước, tuy nhiên khi bức xạ khác nhau, sẽ cho ra điện áp và dòng điện khác nhau. Kết quả từ bảng 3 cho thấy khi nối tiếp các tấm quang điện, điện áp tổng sẽ là tổng các điện áp, dòng điện tổng phát ra của mạch bị giới hạn theo dòng của các tấm quang điện có dòng phát nhỏ. Bảng 4 , cho thấy khi sự cố phủ bóng ảnh hưởng nặng nề đế hệ thống, các tấm quang điện bị phủ bóng lần lược trở thành phụ tải của hệ thống nối tiếp, trường hợp cell 4 bị phủ hoàn toàn thì trong mạch tổng giá trị dòng điện xuống bằng 0 , như một trường hợp hở mạch. 
Trong hệ thống quang điện thực tế, những trường hợp này cần xem xét đến phương án sử dụng diode by pass.

Trường hợp 3: Sử dụng các tấm quang điện ghép nối song song, thực nghiệm các trường hợp có và không có phủ bóng.

Ghép song song các tấm quang điện lại với nhau, nguồn bức xạ sử dụng mức sáng tối đa, sơ đồ thực nghiệm như hình 17.
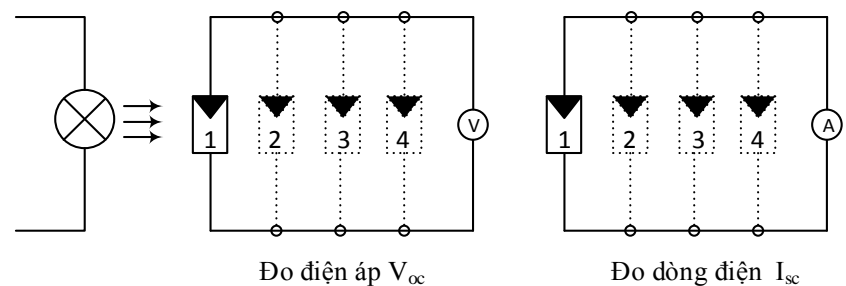

Hình 17: So đồ ghép song song các tấm quang điện.

Tiến hành nối song song lần lượt các tấm quang năng đo $\mathrm{V}_{\mathrm{oc}}$ và $\mathrm{I}_{\mathrm{sc}}$, kết quả đo được trình bày trong bảng 5 như sau:

Bảng 5. Bảng ghi giá trị Voc và Isc khi các cell lần lượt nối song song.

\begin{tabular}{|c|c|c|c|c|}
\hline & Cell 1 & $\begin{array}{c}\text { Song song cell } \\
1 \text { và cell } 2\end{array}$ & $\begin{array}{c}\text { Song song cell 1, } \\
2,3\end{array}$ & $\begin{array}{c}\text { Song song cell 1, 2, } \\
3,4\end{array}$ \\
\hline $\mathrm{U}_{\mathrm{oc}}[\mathrm{mV}]$ & 5,25 & 5,30 & 5,25 & 5,05 \\
\hline $\mathrm{I}_{\mathrm{sc}}[\mathrm{mA}]$ & 112 & 350 & 550 & 675 \\
\hline
\end{tabular}

Vẫn sử dụng các tấm quang điện gắn song song nhau như trên, tiến hành sử dụng các tấm phủ bóng, lần lược tiến hành 4 trường hợp đo: tất cả không phủ; cell 2 phủ $1 \frac{1}{4}$; cell 2 phủ $1 \frac{1}{4}$ và cell 3 phủ $1 \frac{1}{2}$; cell 2 phủ $1 / 4$, cell 3 phủ $1 / 2$ và cell 4 phủ hoàn toàn. Kết quả đo $V_{\mathrm{oc}}$ và $\mathrm{I}_{\mathrm{sc}}$ được ghi trong bảng 6

Bảng 6. Bảng ghi kết quả thí nghiệm Voc và Isc khi có một cell bị phủ bóng

\begin{tabular}{|c|c|c|c|c|}
\hline & $\begin{array}{c}\text { Tất cả không } \\
\text { phủ }\end{array}$ & $1 / 4($ cell 2) & $\begin{array}{c}1 / 4(\text { cell 2)+ } 1 / 2(\text { cell } \\
3)\end{array}$ & $\begin{array}{c}1 / 4(\text { cell 2)+ 1/2 } \\
\text { (cell 3)+phủ cell } \\
4\end{array}$ \\
\hline $\mathrm{U}_{\mathrm{oc}}[\mathrm{mV}]$ & 5,1 & 5,00 & 5,1 & 5,1 \\
\hline $\mathrm{I}_{\mathrm{sc}}[\mathrm{mA}]$ & 680 & 620 & 600 & 570 \\
\hline
\end{tabular}

Kết quả từ bảng 5 , nhận thấy khi các tấm quang điện ghép song song, điện áp hở mạch chung của toàn mạch bị ảnh hưởng bởi tấm quang điện có điện áp phát thâpp, dòng điện ngắn mạch trong mạch sẽ là tổng của các dòng phát ra. Có một trường hợp rất khác biệt, đó là cột 4 trong bảng 6 và cột 4 trong bảng 4 , đây là trường hợp phủ bóng hoàn toàn khi nối tiếp và trường hợp phủ bóng hoàn toàn khi song song. Trường hợp nối tiếp, công suất phát bằng không, trường hợp song song vẫn có công suất phát ra. Hình ảnh thực tế lắp đặt và đo lường được trình bày như hình 18 .

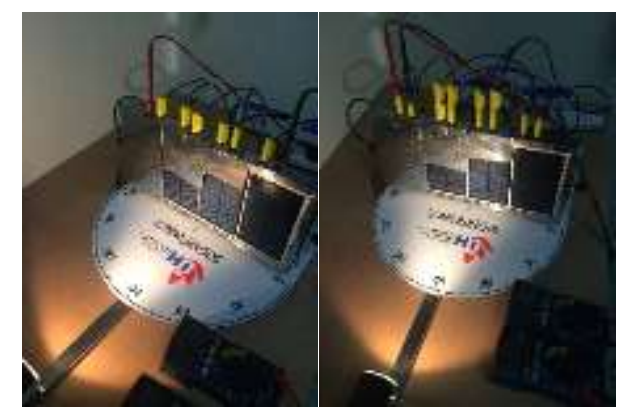

Hình 18: Hình ảnh thực nghiệm tại phòng thí nghiệm. 


\section{KẾT LUẬN}

Thông qua kết quả phân tích sự ảnh hưởng của nhiệt độ lên công suất phát của hệ thống năng lượng mặt trời, nhận thấy cùng một hệ thống nhưng khi nhiệt độ giảm, điện áp, dòng điện và công suất phát của hệ thống tăng. Do đó, khi lắp đặt hệ thống, cần chú ý quan tâm đến vấn đề tản nhiệt của hệ thống, nhất là các hệ thống năng lượng mặt trời áp mái. Trong quá trình phát điện, sự phản ứng hoá học trong tấm quang điện sẽ tích luỹ nhiệt lượng ở phía dưới các tấm quang điện rất cao, do đó nếu không chú ý tản nhiệt tốt thì nhiệt lượng này sẽ làm hệ thống quang năng mau chóng xuống cấp, công suất phát điện của hệ thống sẽ giảm đi đáng kế.

Sự phủ bóng lên bề mặt của các tấm quang điện thường xuyên xảy ra, do đó cần chú ý rất nhiều đến thiết kế các giá đỡ sao cho trong cùng một hệ thống, tấm quang điện này không che phủ các tấm quang điện khác đang hoạt động. Ngoài ra cần chú ý môi trường lắp đặt các tấm quang điện như bụi bẩn, rác, lá cây sẽ phủ lên bề mặt các tấm quang điện làm ảnh hưởng đến công suất phát của hệ thống, do đó cần xây dựng chế độ bảo trì và bảo hành thường xuyên liên tục cho các hệ thống năng lượng mặt trời để không làm giảm công suất phát điện của hệ thống theo thời gian./.

\section{LỜI CẢM ƠN}

Bài viết này là kết quả nghiên cứu thuộc đề tài "Bộ KIT thí nghiệm năng lượng mặt trời phục vụ giảng dạy" năm 2018. Tác giả cùng các cộng sự xin chân thành cảm ơn Ban Giám Hiệu Trường Đại Học Công Nghiệp TP.HCM đã cấp kinh phí triển khai thực hiện đề tài này.

\section{TÀI LIỆU THAM KHẢO}

[1] M. Thư, "Chi Phí Sản Xuất Năng Lượng Tái Tạo Đang Giảm Đáng Kể," Forbes Việt Nam, 2018.

[2] N. M. Hiền, "Tổng quan tiềm năng và triển vọng phát triển năng lượng tái tạo Việt Nam," Năng Lượng Việt Nam, 2019.

[3] N.D.Cuong, WB, MoIT, IE and EVN, "Renewable Energy in Vietnam - potential and current utilization," MOIT/GIZ Energy Support Programme, 2016.

[4] S.O.Kasap, "Optoelectronics and Photonics: principles and Practices", Second Edition, 2013, Pearson Education, USA

[5] A. D. Rajapakse and D. Muthumuni, "Simulation Tools for Photovoltaic System Grid Integration Studies," IEEE Electrical Power and Energy Conference, EPEC, 2009.

[6] R. Ramaprabha and B. L. Mathur, "A Comprehensive Review and Analysis of Solar Photovoltaic Array Configurations under Partial Shaded Conditions,” International Journal of Photoenergy, 2012.

[7] R. Ramaprabha and B. L. Mathur, "Effect of Shading on Series and Parallel Connected Solar PV Modules," Modern Applied Science, Vol.3, No.10, October 2009.

[8] R. Ramaprabha and B. L. Mathur, "Impact of Partial Shading on Solar PV Module Containing Series Connected Cells," International Journal of Recent Trends in Engineering, Vol 2, No. 7 , November 2009.

Ngày nhận bài:07/08/2019

Ngày chấp nhận đăng:01/10/2019 